\title{
Den akutt syke hjernen må håndteres allerede prehospitalt
}

\author{
Tid er hjerne, tid er funksjon. For at pasienter med symptomer på akutt hjernelidelse skal få best mulig utfall, \\ bør radiologisk diagnostikk og spesifikk behandling starte allerede prehospitalt.
}

Behandlingsresultatet ved akutte hjernelidelser er svært tidsavhengig. Hjernen krever kontinuerlig tilførsel av oksygenrikt blod, og opphørt sirkulasjon til et mindre eller større hjernevolum vil etter svært kort tid føre til redusert celleaktivitet med påfølgende celledød. En akutt reduksjon i blodtilførsel til hjernevev er i opptil $85 \%$ av tilfellene forårsaket av en okkluderende trombe (cerebral iskemi) og i drøyt $10 \%$ av cerebral blødning (1). En trombe kan løses opp medikamentelt med intravenøs trombolytisk behandling eller fjernes mekanisk med trombektomi. Tiden fra blodforsyningen reduseres til den reetableres er avgjørende for pasientens videre liv og funksjon. Ved rask behandling kan mye hjernevev overleve. Ved en hjerneblødning vil en tidlig senkning av blodtrykket kunne begrense skadeomfanget. Hodetraumer kan medføre knusningsskade og blødning i og rundt hjernen, og rask nevrokirurgisk behandling kan være livreddende.

\section{Radiologisk diagnostikk}

Behandling av akutte hjernelidelser forutsetter rask diagnostikk, og det er kun CT og MR av hjernen som kan skille blødning fra iskemi. Alle pasienter med symptomer på akutt hjernelidelse må få en rask radiologisk avklaring før spesifikk behandling igangsettes. Studier har vist at både blodtrykkssenkning ved hjerneblødning (2) og trombolytisk behandling ved cerebral iskemi kan gis utenfor sykehus på en trygg måte $(3,4)$.

Per 2016 finnes det intet tilbud om radiologisk hjernediagnostikk i prehospital fase. Skal visjonen om tidligst og best mulig behandling av den akutt syke hjernen bli virkeliggjort, må helt nye modeller utvikles og testes. Prehospital radiologisk diagnostikk kan tenkes enten som en ambulant eller stasjonær tjeneste, tilgjengelig «der folk bor».

\section{Den unødig lange reisen}

I Altaposten i januar 2016 fortalte tidligere Kautokeino-ordfører Klemet Erland Hætta (5) sin historie. Hætta ble rammet av hjerneslag i 2004, og veien til diagnose og spesifikk behandling gikk mange mil og timer fra Kautokeino via Alta til Hammerfest sykehus, der han etter en CT-undersøkelse ble fraktet videre til Universitetssykehuset Nord-Norge i Tromsø. Hadde det vært et hjernediagnostisk tilbud med CT i Alta, ville diagnosen vært klar mange viktige timer før og en lang transportvei til endelig behandlingssted ville blitt vesentlig kortere.

\section{«En prehospital og desentralisert radio- logisk diagnostikk av den akutt syke hjernen kan redde liv og fore- bygge mye lidelse»}

Historien til Hætta er på ingen måte unik, men illustrerer godt den lange reisen mange som rammes av akutte hjernetilstander i Norge må legge ut på.

En prehospital radiologisk diagnose Siden oktober 2014 har Stiftelsen Norsk Luftambulanse i samarbeid med Oslo universitetssykehus og Sykehuset Østfold drevet en studie om prehospital diagnostikk av akutte hjernetilstander. Resultatene fra denne studien er ennå ikke analysert, men vi har utført 70 prehospitale cerebral CTundersøkelser på pasienter med klinisk mistanke om akutt hjerneslag eller som har vært utsatt for et akutt hodetraume. De prehospitale CT-undersøkelsene er utført i en spesialbygd ambulanse utstyrt med en CT-maskin, et portabelt laboratorium og teleradiologisk utstyr. Ambulansen er bemannet som et ambulansehelikopter med anestesilege, paramedisiner og sykepleier med ambulansefagbrev, og har alt nødvendig utstyr for å utøve akuttmedisin. Alle CT-undersøkelser er utført og tolket av anestesilegen ombord, samtidig som bildene umiddelbart er blitt sendt teleradiologisk til sykehuset. I denne ambulante modellen har man i tett samarbeid med sykehusets vakthavende nevrologer og radiologer avdekket eventuelle kontraindikasjoner mot trombolysebehandling, som intrakranial blødning, stort akutt infarkt eller annen cerebral patologi. Enkelte pasienter med intrakranial blødning er blitt sendt direkte til nevrokirurgisk avdeling på regionsykehuset. I neste fase av denne stu- dien planlegger vi oppstart av prehospital trombolysebehandling.

Vår ambulansemodell har vist at det er mulig å utføre cerebral CT-diagnostikk på en rask, skånsom og presis måte med en bemanning som på et vanlig ambulansehelikopter. En prehospital og desentralisert radiologisk diagnostikk av den akutt syke hjernen kan redde liv og forebygge mye lidelse. Et slikt tilbud bør være på plass i Norge i løpet av få år.

\section{Maren Ranhoff Hov \\ maren.ranhoff.hov@norskluftambulanse.no Christian Georg Lund}

Maren Ranhoff Hov (f. 1983) er cand.med., doktorgradsstipendiat ved Stiftelsen Norsk Luftambulanse og har prehospital erfaring fra ambulansetjenesten i Indre Troms (UNN HF). Forfatter har fylt ut ICMJE-skjemaet og oppgir ingen interessekonflikter.

Christian Georg Lund (f. 1961) er dr.med., spesialist i nevrologi og overlege ved Nevrologisk avdeling, Oslo universitetssykehus, Rikshospitalet og ved Stiftelsen Norsk Luftambulanse Forfatter har fylt ut ICMJE-skjemaet og oppgir ingen interessekonflikter.

\section{Litteratur \\ 1. Norsk hjerneslagsregister. Resultater fra Norsk hjerneslagregister. www.kvalitetsregistre.no/ resultater/hjerte-og-kar/norsk-hjerneslag- register/resultater/ (22.2.2016). \\ 2. Walter S, Kostpopoulos P, Haass A et al. Bringing the hospital to the patient: first treatment of stroke patients at the emergency site. PLoS ONE 2010; 5: e13758. \\ 3. John S, Stock S, Cerejo R et al. Brain Imaging Using Mobile CT: Current Status and Future Pro- spects. J Neuroimaging 2015 \\ 4. Walter S, Kostopoulos P. Haass A et al. Diagnosis and treatment of patients with stroke in a mobile stroke unit versus in hospital: a randomised con- trolled trial. Lancet Neurol 2012; 11: 397-404. \\ 5. Mjøen J. Klemets slaghistorie gir CT - jeg er glad for å ha bidratt til at det blir utplassert CT i Alta. Altaposten 15.01.16. www.altaposten.no/lokalt/ nyheter/2016/01/15/Klemets-slaghistorie-gir-CT- 12033844.ece (15.1.2016).}

Mottatt 18.2. 2016, første revisjon innsendt 22.2. 2016, godkjent 25.2. 2016. Redaktør: Ketil Slagstad.

Publisert først på nett. 